\title{
POJAVNOST SUICIDALNOSTI U BOLESNIKA HOSPITALIZIRANIH NA KLINICI ZA PSIHIJATRIJU SKB MOSTAR U PERIODU 2004,-2013.
}

\author{
Marko Pavlovići, ${ }^{1,2}$, Martina Krešić Ćorić ${ }^{1,2}$, Katica Nikolić ${ }^{1}$, Nataša Dodoš ${ }^{1}$, Krešimir Grbavac ${ }^{1}$, Romana \\ Babić $^{1}$, Sanjin Lovrić ${ }^{1}$, Bojan Bender ${ }^{1}$, Sanja Burić ${ }^{1}$, Dragan Babić ${ }^{1,2}$ \\ ${ }^{1}$ Klinika za psihijatriju, Sveučilišna klinička bolnica Mostar, 88000 Mostar, Bosna i Hercegovina \\ ${ }^{2}$ Medicinski fakultet, Sveučilište u Mostaru, 88000 Mostar, Bosna i Hercegovina \\ Rad je primljen 5.1.2016. \\ Rad je korigiran 20.2.2016. \\ Rad je prihvaćen 26.3.2016.
}

UVOD: I pored evidentnog napretka medicine i psihijatrije posljednjih desetljeća se registrira porast suicidalnosti psihijatrijskih bolesnika. Osobe koje se poradi nekog oblika suicidalnog ponašanja hospitaliziraju u psihijatrijskim ustanovama predstavljaju populaciju s posebice visokim rizikom od naknadnog suicida.

CILJ: Istražiti pojavnost suicidalnosti i epidemiološke karakteristike suicidalnih bolesnika hospitaliziranih na Klinici za psihijatriju Sveučilišne kliničke bolnice (SKB) Mostar.

METODE: Proveli smo retrospektivno istraživanje u kojemu smo analizirali podatke iz povijesti bolesti 189 bolesnika koji su hospitalizirani na Klinici za psihijatriju SKB Mostar u razdoblju od 2004. do 2013.

REZULTATI: Bolesnici koji su pokušali suicid češće su bili ženskog spola (59,2 \%), nezaposleni (47,6 \%), srednjeg stupnja obrazovanja (52,4 \%), oženjeni (45,5\%), bez djece (37,6 \%) te su učestalije dolazili iz gradskih sredina (75,7 \%). Nije nađeno razlika u učestalosti pokušaja suicida između muškaraca i žena s obzirom na kalendarske karakteristike. Žene su statistički značajno učestalije imale dijagnoze iz skupine afektivnih i poremećaja ličnosti, dok su muškarci statistički značajno učestalije bolovali od poremećaja iz shizofrenog kruga $(\mathrm{p}=0,003)$. Najučestalija metoda pokušaja suicida je bila trovanje $(54,0 \%)$, a promatrano po spolu značajno učestalije u žena $(\mathrm{p}<0,001)$. Muškarci su značajno učestalije pokušavali suicid tjelesnim ozljeđivanjem ( $<<0,001)$, te zloupotrebljavali alkoholna pića $(\mathrm{p}=0,001)$ i psihoaktivne tvari $(\mathrm{p}=0,003) \mathrm{u}$ odnosu na žene.

ZAKLJUČAK: Pokušaji suicida su bili učestaliji u osoba ženskog spola. Žene su statistički značajno učestalije imale dijagnoze iz skupine afektivnih i poremećaja ličnosti, dok su muškarci statistički značajno učestalije bolovali od poremećaja iz shizofrenog kruga. Žene su statistički značajno učestalije pokušavale suicid trovanjem, a muškarci tjelesnim ozljeđivanjem. Ključne riječi: pokušaj suicida, hospitalizacija, retrospektivna studija

Osoba za razmjenu informacija:

mr. sc. Marko Pavlović, dr. med.

e-mail:makijato29@gmail.com

\section{UVOD}

I pored evidentnog napretka medicine i psihijatrije posljednjih desetljeća se registrira porast suicidalnosti psihijatrijskih bolesnika i u izvanhospitalnim i u hospitalnim uvjetima. Suicidalno ponašanje i pokušaji suicida predstavljaju danas jedan od vodećih problema $s$ kojima rade profesionalci u području mentalnog zdravlja, a često su uzrok i urgentnog tretmana te psihijatrijskih hospitalizacija (1). Niti jedna zemlja u svijetu u današnje vrijeme ne posjeduje službene statističke podatke o ukupnom broju pokušaja suicida što čini nemogućom usporedbu broja pokušanih suicida s brojem kompletnih suicida na razini bilo koje zemlje. S druge strane statistički podaci o kompletnim suicidima su dostupni za sve razvijene zemlje svijeta te za većinu zemalja u razvoju i isti se redovito skupljaju i obrađuju od strane Svjetske zdravstvene organizacije (SZO) (2). Prema podacima SZO od 1950. do 2004., postoji trend povećanja globalne stope suicida, osobito u muškaraca (3). Neke druge procjene i projekcije s obzirom 
na sadašnje podatke sugeriraju da će se broj suicida povećati i do $50 \%$ u periodu od 2002. do 2030. (4).

Prema definiciji Skupštine SZO (engl. World Health Assembly) pokušaj suicida ili suicidalno ponašanje s nesmrtnim posljedicama je samougrožavanje i samoozljeđivanje u želji da se okonča vlastiti život, a koje ne završava smrću (5).

Pokušaji suicida predstavljaju danas značajan javnozdravstveni problem koji je povezan s visokim morbiditetom (6). Prema istraživanjima SZO oko 0,5-1,4 \% ljudi u svijetu umre zato što počini suicid $(7,8)$. Podaci ukazuju i na to da na svaki počinjeni suicid postoji oko 10 do 40 pokušaja suicida (8). Prema nekim procjenama od 200,000-1.000,000 ljudi u Sjedinjenim Američkim Državama (SAD) te oko 700,000 ljudi u Europi pokušava suicid tijekom jedne godine (9). U zemljama Zapada, muškarci tri do četiri puta češće umiru od žena zbog izvršenog suicida, iako žene pokušaju suicid četiri puta češće od muškaraca $(7,8)$. Najveća incidencija pokušaja suicida u Europi se viđa u osoba ženskog spola mlađe životne dobi, od 15.-24. godine (10).

Pod visoko rizičnim čimbenicima suicidalnosti podrazumijevaju se:

a. karakteristični oblici u ponašanju (izražavanje sucidalnih misli, pravljenje planova, preokupiranost razmišljanjima o smrti, druge promjene ponašanja);

b. demografske karakteristike (spol, dob, mjesto stanovanja);

c. socijalni čimbenici (samci, neuposlene osobe, socijalno izolirane osobe, osobe s niskim ekonomskim statusom, osobe iz razorenih obitelji);

d. ovisnost o alkoholu ili psihoaktivnim tvarima;

e. pojava neke bolesti ili raniji pokušaj suicida (1113).

Raniji pokušaj suicida je, prema dosadašnjim istraživanjima, najznačajniji prediktor suicidalnosti $(1,11,14,15)$. Rizik smrtnog ishoda kod ljudi koji su ranije pokušali suicid je stotinu puta veći nego u općoj populaciji, dok 10-15 \% osoba koji su pokušali suicid umire zbog naknadno izvršenog suicida $(15,16)$. Najveći rizik smrtnosti je u periodu od 6 mjeseci nakon prethodnog pokušaja suicida, posebno u muškaraca (12).
Postojanje psihičkih poremećaja (poremećaji raspoloženja, poremećaji kontrole impulsa, zlouporaba/ovisnost o alkoholu ili drogama, psihotični poremećaji te poremećaji ličnosti) spadaju također u najvažnije rizične čimbenike suicidalnog ponašanja koji se spominju u literaturi (11).

Više od $90 \%$ pokušaja suicida u svijetu izvrši se trovanjem lijekovima (najčešće benzodiazepinima), dok novija istraživanja iz naše regije potvrđuju da je to najčešći način pokušaja suicida u oba spola (1720).

Postoje dokazi da i niz drugih rizičnih čimbenika utječe na suicidalno ponašanje, kao što su dostupnost vatrenog oružja ili raznih lijekova, kronične ili terminalne bolesti, homoseksualnost, prisustvo suicidalnog ponašanja među vršnjacima te određeno doba godine (najčešće u proljeće te mjesecima svibnju i lipnju) (21-26).

Osobe koje se poradi nekog oblika suicidalnog ponašanja hospitaliziraju u psihijatrijskim ustanovama predstavljaju populaciju s posebice visokim rizikom od naknadnog suicida. Usprkos tome, većina dosadašnjih istraživanja se fokusirala na proučavanje karakteristika vezanih uz kompletne suicide dok se vrlo malo pažnje posvećivalo osobama koje se hospitaliziraju nakon pokušaja suicida unatoč činjenici da je hospitalizacija nakon pokušaja suicida zapravo i šansa za provođenje adekvatnog tretmana i prevencije budućeg suicidalnog ponašanja kod bolesnika za koje je poznato da imaju povišeni rizik od naknadnog suicida.

\section{CILJ ISTRAŽIVANJA}

Istražiti pojavnost suicidalnosti i epidemiološke karakteristike suicidalnih bolesnika hospitaliziranih na Klinici za psihijatriju Sveučilišne kliničke bolnice (SKB) Mostar.

\section{ISPITANICI I METODE}

Uradili smo retrospektivno istraživanje u kojemu smo pretražili ukupno 5011 povijesti bolesti bolesnika koji su hospitalizirani na Klinici za psihijatriju SKB Mostar u razdoblju od 1. siječnja 2004. do 31. prosinca 2013., iz čega smo izdvojili bolesnike koji su hospitalizirani poradi pokušaja suicida. U 
istraživanje nisu uključeni bolesnici koji su zbog pokušaja suicida hospitalizirani na drugim odjelima i klinikama SKB Mostar a koji iz bilo kojeg razloga nisu premješteni na Kliniku za psihijatriju (npr. odbijanje psihijatrijskog tretmana, potreba za dugotrajnim nastavkom somatskog tretmana, premještaj u drugu ustanovu). U istraživanje nisu uključeni ni pacijenti koji su pri dolasku na psihijatriju odbili psihijatrijsku hospitalizaciju, a nad kojima se nije mogao sprovesti prisilni smještaj.

Analizirali smo učestalost i raspodjelu pokušaja suicida s obzirom na:

a) sociodemografske karakteristike ispitanika (spol, dob, mjesto stanovanja, obrazovanje, radni, bračni i stambeni status, broj djece);

b) kliničke i druge karakteristike (vrsta psihijatrijskog poremećaja koji je prethodio pokušaju suicida, ranije psihijatrijsko liječenje, broj prethodnih hospitalizacija, postojanje psihijatrijskog herediteta i ranijih pokušaja suicida, način izvršenja, prethodni teški životni događaji, komorbiditet s ovisnostima, sudioništvo u prethodnom ratu, ranjavanje, zarobljeništvo);

c) kalendarske karakteristike (dan, mjesec i godišnje doba).

Istraživanje je provedeno uz odobrenje Etičkog odbora SKB Mostar.

\section{Statističke metode obrade podataka}

Statistički testovi za obradu podataka su izabrani ovisno o vrsti varijabli. Za nominalne i ordinalne varijable koristio se hi kvadrat test, a pri manjku očekivane frekvence Fisherov egzaktni test te Yatesova korekcija. Statistički testovi kojima su se analizirale kontinuirane varijable odabrani su na temelju simetričnosti raspodjele podataka. Kod simetrične raspodjele podataka, za usporedbu dvije nezavisne varijable korišten je Studentov t-test. Za statistič$\mathrm{ku}$ analizu koristio se programski sustav SPSS for Windows (inačica 17.0, SPSS Inc, Chicago, Illinois, SAD) i Microsoft Excell (inačica 11. Microsoft Corporation, Redmond, WA, SAD).

\section{REZULTATI}

U istraživanom periodu ukupno je 189 ispitanika hospitalizirano nakon pokušaja suicida, od čega su $59,2 \%(\mathrm{n}=100)$ bile žene, a 40,8 \% ( $\mathrm{n}=89)$ muškarci (Slika 1).

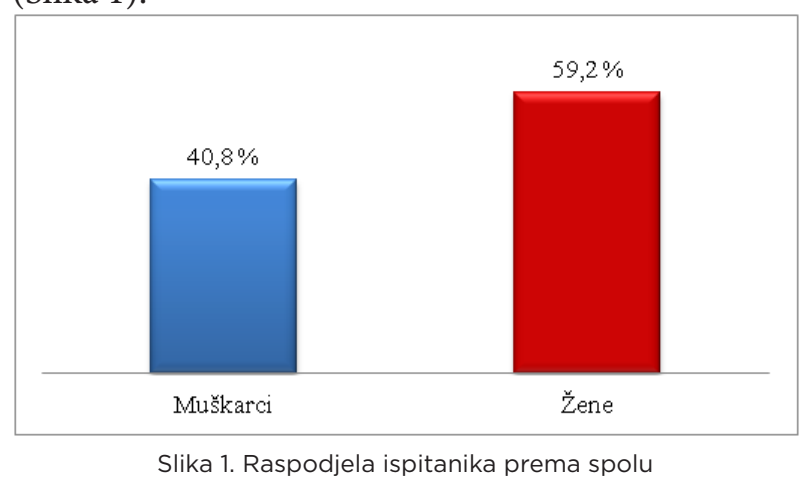

Broj ispitanika hospitaliziranih zbog pokušaja suicida pokazuje porast od 2004.-2006., potom slijedi značajan pad do 2008. te ponovni porast do 2011. i potom blagi pad do kraja ispitivanog perioda. $\mathrm{U}$ većem dijelu analiziranog perioda broj žena bio je značajno veći osim za period od 2004.-2005. te od 2011. do kraja ispitivanog perioda (Slika 2).

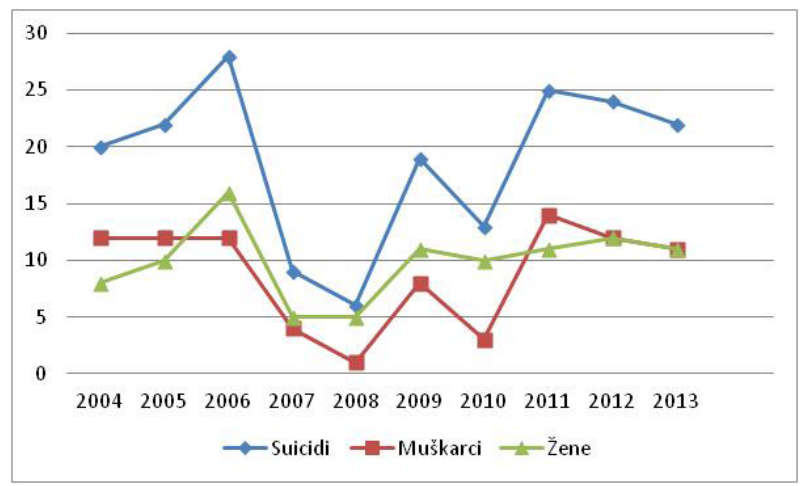

Slika 2. Prikaz broja pokušaja suicida prema godinama

Dobiveni rezultati pokazali su da su žene bile statistički značajno mlađe životne dobi u odnosu na ispitanike muškog spola $(\mathrm{t}=2,381 ; \mathrm{p}=0,018)$ (Slika 3 ). 


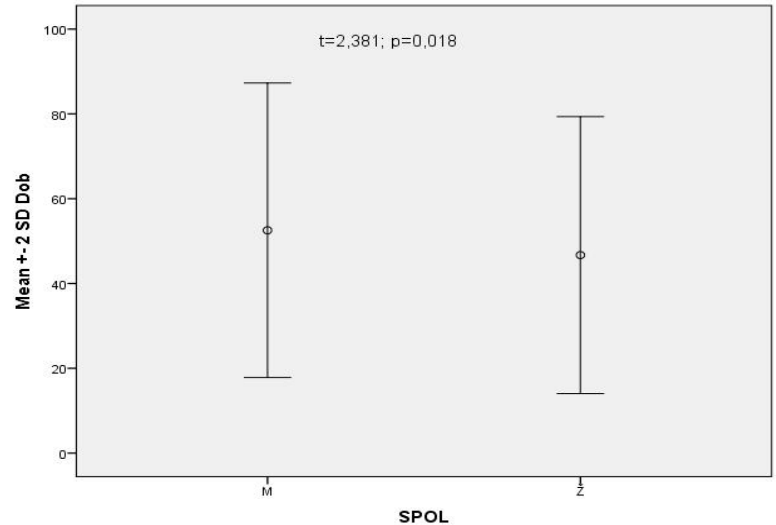

Slika 3. Dobne karakteristike ispitanika

Promatrajući mjesto stanovanja nađeno je da je većina od ukupnog broja ispitanika, njih $75,7 \%$ $(\mathrm{n}=143)$ dolazilo iz gradskih sredina. Nije nađeno statistički značajne razlike u učestalosti pokušaja suicida između muškaraca i žena s obzirom na mjesto stanovanja $\left(\chi^{2}\right.$ test $\left.=0,539 ; \mathrm{p}=0,463\right)$.

Najveći udio ispitanika bili su nezaposleni $(47,6 \%)$, osobe s vlastitom kućom ili stanom (43,9\%), osobe nižeg $(31,7 \%)$ i srednjeg stupnja obrazovanja $(52,4 \%)$, te osobe bez djece $(37,6 \%)$. Oženjeni ispitanici bili su podjednako zastupljeni kao i ispitanici koji nisu u braku (razvedeni i neoženjeni) (45,5\%).

Nije nađeno statistički značajnih razlika u učestalosti pokušaja suicida između muškaraca i žena promatrajući obrazovanje $\left(\chi^{2}\right.$ test $=4,052$; $\mathrm{p}=0,132)$, bračni ( $\chi^{2}$ test $\left.=1,655 ; \mathrm{p}=0,727\right)$ i stambeni ( $\chi^{2}$ test $\left.=2,591 ; p=0,430\right)$ status te broj djece $\left(\chi^{2}\right.$ test $\left.=2,791 ; \mathrm{p}=0,425\right)$, dok promatrajući radni status statistički značajno učestalije nezaposlene žene i umirovljeni muškarci pokušavaju suicid $\left(\chi^{2}\right.$ test $=28,355 ; \mathrm{p}<0,001$ ).

Najveći broj pokušaja suicida izvršen je utorkom $(18,0 \%)$ te u mjesecima travnju (10,6\%) i svibnju (10,6 \%). U promatranom razdoblju ispitanici su najčešće pokušali suicid u proljeće $(30,7 \%)$ i ljeto $(29,6 \%)$, zatim u jesen $(20,1 \%)$, a najrjeđe zimi (19,6 \%). Nije postojala statistički značajna razlika u učestalosti pokušaja suicida između muškaraca i žena promatrajući dan $\left(\chi^{2}\right.$ test $\left.=9,473 ; p=0,149\right)$, mjesec $\left(\chi^{2}\right.$ test $\left.=8,088 ; p=0,705\right)$ i godišnje doba $\left(\chi^{2}\right.$ test $=3,093 ; \mathrm{p}=0,377)$.
Najveći broj ispitanika je imao neku od dijagnoza iz skupine afektivnih poremećaja (24,9\%), potom iz skupine shizofrenija, shizotipni i sumanuti poremećaj (22,8 \%), te poremećaja ličnosti (19,0\%) (Slika $4)$.

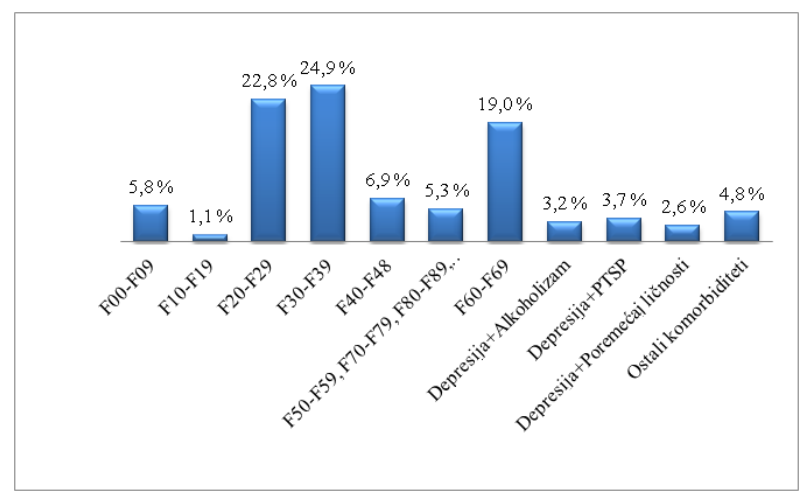

Slika 4. Raspodjela ispitanika prema dijagnostičkim kategorijama

Žene su statistički značajno učestalije imale dijagnoze iz skupine afektivnih i poremećaja ličnosti, dok su muškarci statistički značajno učestalije bolovali od poremećaja iz shizofrenog kruga $\left(\chi^{2}\right.$ test $=25,088 ; p=0,003$ ) (Slika 5). Nije nađeno statistički značajnih razlika među spolovima unutar drugih dijagnostičkih skupina.

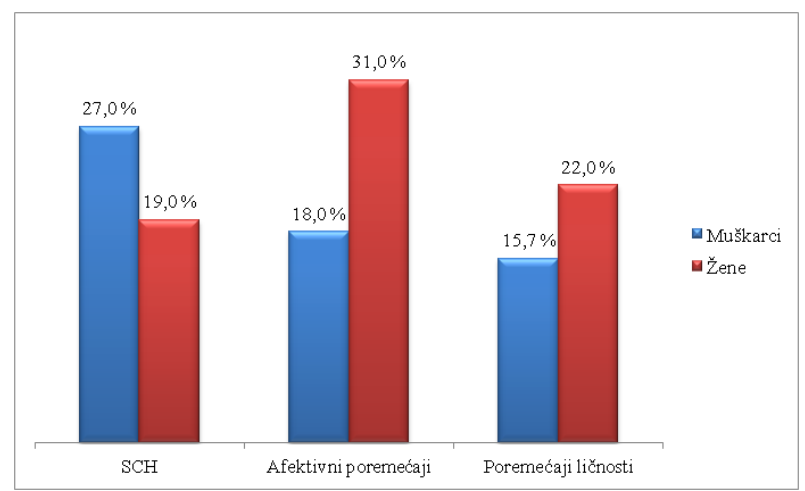

Slika 5. Spolna raspodjela u najznačajnijim dobnim skupinama

Najučestalija metoda pokušaja suicida je bila trovanje $(54,0 \%)$, zatim nanošenje tjelesne povrede $(26,5 \%)$ te potom gušenje ili vješanje $(10,6 \%)$ (Slika $6)$. 


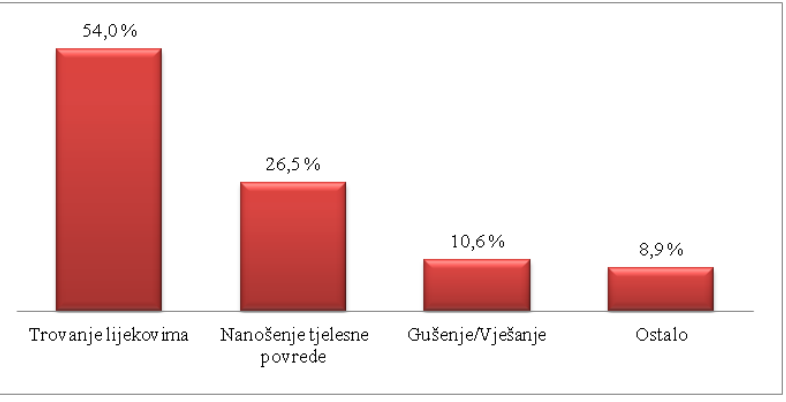

Slika 6. Učestalost metoda pokušaja suicida

Žene su statistički značajno učestalije pokušale suicid trovanjem $(69,0 \%)$, a muškarci tjelesnim ozljeđivanjem $(37,1 \%)\left(\chi^{2}\right.$ test $\left.=20,054 ; \mathrm{p}<0,001\right)$. Muški ispitanici su također nešto češće pokušavali suicid vješanjem ili gušenjem u odnosu na žene ali te razlike nisu bile statistički značajne (Slika 7).

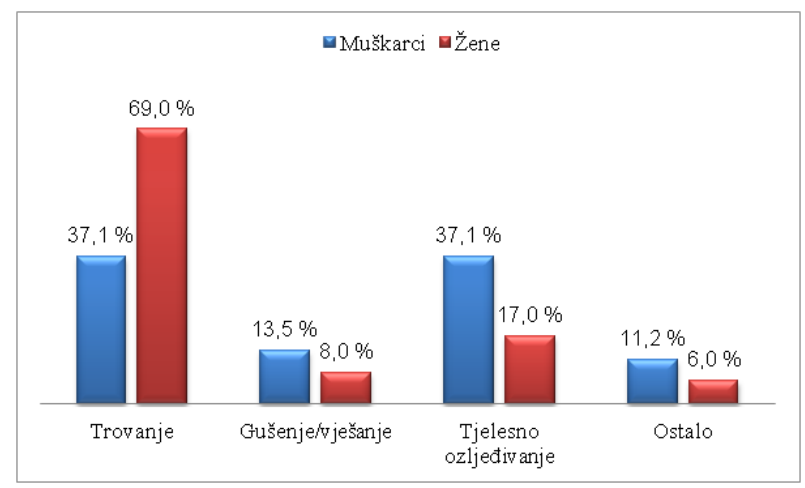

Slika 7. Spolna raspodjela ispitanika u odnosu na način izvršenja

Većina ispitanika je od ranije bila u nekoj vrsti psihijatrijskog tretmana (ambulantno ili hospitalno) $(65,1 \%)$, a statistički značajno učestalije su to bile ženske osobe ( $\chi^{2}$ test $\left.=5,146 ; p=0,023\right)$. Više od polovice $(55,0 \%)$ bolesnika je po prvi put psihijatrijski hospitalizirano, i to muškarci statistički značajno učestalije nego žene ( $\chi^{2}$ test $\left.=6,166 ; p=0,046\right)$.

Nešto više od $1 / 4$ svih ispitanika $(27,0 \%)$ ranije je pokušalo suicid, pri čemu nije bilo statistički značajnih razlika među spolovima $\left(\chi^{2}\right.$ test $=0,144$; $\mathrm{p}=0,704)$.

Pozitivan psihijatrijski hereditet imalo je 21,7 \% ispitanika, dok u 33,3 \% ispitanika nije nađeno nikakvih podataka o hereditetu. Među ispitanicima za koje su postojali anamnestički podaci nije nađeno statistički značajnih razlika među spolovima u pogledu psihijatrijskog herediteta $\left(\chi^{2}\right.$ test $=4,222$; $\mathrm{p}=0,090$ ). Suicid u obitelji zabilježen je u samo $9,0 \%$ ispitanika dok u većine ispitanika (63,5 \%) nismo našli nikakve podatke o tome u povijestima bolesti. Kod ispitanika za koje su postojali navedeni podaci nije nađeno statistički značajnih razlika među spolovima ( $\chi^{2}$ test $\left.=3,487 ; p=0,155\right)$.

Prema anamnestičkim podacima $66,1 \%$ ispitanika nije doživjelo neki teži životni događaj pred pokušaj suicida, dok značajnih razlika među spolovima u učestalosti prethodnog težeg životnog događaja nije pronađeno $\left(\chi^{2}\right.$ test $\left.=0,529 ; p=0,467\right)$.

Muški ispitanici su statistički značajno učestalije od žena zloupotrebljavali alkoholna pića $\left(\chi^{2}\right.$ test $\left.=10,374 ; \mathrm{p}=0,001\right)$ i psihoaktivne tvari $\left(\chi^{2}\right.$ test $=8,590 ; \mathrm{p}=0,003)$, bili sudionici Domovinskog rata $\left(\chi^{2}\right.$ test $\left.=26,889 ; \mathrm{p}<0,001\right)$ te ranjavani $\left(\chi^{2}\right.$ test $=8,398 ; \mathrm{p}=0,004)$.

\section{RASPRAVA}

Rezultati našeg istraživanja koji govore u prilog značajno veće učestalosti pokušaja suicida u osoba ženskog spola zapravo potvrđuju rezultate brojnih dosadašnjih istraživanja koji govore o tipičnim spolnima razlikama i značajno većoj učestalosti suicidalnog ponašanja i pokušaja suicida u žena u odnosu na muškarce, odnosno govore u prilog postojanja tzv. „spolnog paradoksa“ u suicidima (27-29).

Rezultati vezani uz dob ispitanika idu u prilog dosadašnjim istraživanjima koja govore o najvećem suicidalnom riziku u osoba mlađe životne dobi i ženskog spola (30).

S obzirom na mjesto stanovanja naši rezultati pokazuju da većina ispitanika oba spola živi u gradskim područjima što se dijelom može objasniti pojačanom migracijom stanovništva iz ruralnih u urbana područja u postratnom periodu te većim stresom koje donosi život u urbanim područjima (31).

Demografski podaci (radni status, obrazovanje, bračni status) iz našeg istraživanja u skladu su $s$ dosadašnjim spoznajama o drugim demografskim rizičnim čimbenicima suicidalnog ponašanja koji uključuju nezaposlene osobe, osobe nižeg obrazovanja te osobe koje nisu u braku (32). Ovi demografski čimbenici mogu biti povezani s povišenim suicidalnim rizikom preko socijalnih ograničenja koje nose sa sobom, mada zapravo mehanizmi preko kojih dovode do povećanja suicidalnog rizika još 
uvijek nisu dovoljno jasni. Visoki udio oženjenih osoba među našim ispitanicima možemo tumačiti relativno malim ukupnim uzorkom, nekim kulturološkim i religioznim razlozima vezanim uz područje Hercegovine, te činjenicom da za 8,5\% ispitanika iz našeg istraživanja nisu postojali anamnestički podaci o bračnom stanju.

Sezonska asimetrija u broju pokušaja suicida je fenomen koji je u psihijatriji poznat unatrag dužeg niza godina. Rezultati našeg istraživanja potvrđuju rezultate drugih istraživanja koji su pronašli veću učestalost pokušaja suicida u proljeće i ljeto te tijekom mjeseca travnja, svibnja i lipnja $(33,34)$.

Prisustvo psihijatrijskog poremećaja se, prema brojnim dosadašnjim istraživanjima, ubraja među najdosljednije rizične čimbenike suicidalnog ponašanja pri čemu poremećaji raspoloženja, poremećaji kontrole impulsa, ovisnost o alkoholu i psihoaktivnim tvarima, psihotični poremećaji te poremećaji ličnosti nose sa sobom najveći rizik neovisan o spolu (35-40). Ispitanici iz našeg istraživanja najučestalije su imali neki od afektivnih poremećaja, a potom neki od poremećaja iz shizofrenog kruga, što je u skladu s rezultatima sličnih istraživanja iz naše regije (19).

Od ranije je poznato da se metode pokušaja suicida razlikuju među različitim kulturama i regijama te da muškarci češće koriste metode koje nose veći rizik od smrti $(41,42)$. Trovanje lijekovima, koje je bilo najučestalija metoda u našem istraživanju, je također najučestalija metoda pokušaja suicida i prema drugim istraživanjima iz naše regije ali i šire $(14,20)$. Naši rezultati također potvrđuju i rezultate drugih istraživanja prema kojima žene učestalije pokušavaju suicid trovanjem u odnosu na muškarce, kao i da muškarci češće koriste agresivnije suicidalne metode $(19,27)$.

Rezultati vezani uz psihijatrijski tretman u skladu su s rezultatima nekoliko ranijih istraživanja provedenih na suicidalnim bolesnicima u urgentnim odjelima a koji su pokazali da je 50-69 \% suicidalnih bolesnika prethodno imalo neku vrstu psihijatrijskog tretmana $(40,43,44)$. Rezultati o učestalijem ranijem psihijatrijskom liječenju u osoba u ženskog spola vjerojatno su posljedica učestalije zastupljenosti prvih hospitalizacija u muških ispitanika.

Većina teoretskih modela suicidalnog ponašanja predlaže postojanje tzv. dijateza-stres modela prema kojemu određeni psihijatrijski, psihološki i biološki čimbenici predisponiraju osobu prema suicidalnom ponašanju, dok stresni životni događaji djeluju s takvim čimbenicima u smislu povećavanja suicidalnog rizika. Među njima su osobito česti događaji u uskim interpersonalnim odnosima (npr. sukob, odvajanje, smrt bliske osobe), događaji vezani za životnu situaciju (gubitak posla, financijski problemi, bolest člana obitelji) te događaji vezani za zdravstveno stanje (tjelesna ili psihička bolest, abortus). Životni događaji i problemi koji prethode pokušaju suicida prema većini istraživanja se evidentiraju u 60-80 \% ispitanika $(1,45)$. U suprotnosti s navedenim, prema našim podacima samo je $1 / 3$ bolesnika prethodno imala neki od evidentiranih težih životnih događaja pri čemu je vrlo važno istaći da podaci o ovome u našem istraživanju nisu sustavno prikupljani ciljanim upitnicima nego skupljanjem podataka iz povijesti bolesti što značajno umanjuje pouzdanost dobivenih rezultata i ograničava njihovu interpretaciju. Naime u povijestima bolesti često nisu niti navedeni ovi podaci, najčešće zbog nesistematiziranog unošenja podataka u povijesti bolesti ili čak i zbog smanjena naknadne stigmatizacije bolesnika.

Zlouporaba i ovisnost o alkoholu i psihoaktivnim tvarima se, kako je već ranije navedeno, ubrajaju među neke od najvažnijih rizičnih čimbenika suicidalnog ponašanja. Veća učestalost zlouporabe alkoholnih pića i psihoaktivnih tvari u muških ispitanika iz našeg istraživanja potvrđuje rezultate ranijih sličnih istraživanja koji govore o većoj učestalosti bolesti ovisnosti u muškaraca koji pokušavaju suicid u odnosu na žene $(40,46)$. Rezultati u pogledu sudjelovanja u ratu i ranjavanju su logični i očekivani s obzirom da su aktivni sudionici rata u velikoj većini bili muškog spola.

U našem istraživanju postojalo je nekoliko ograničenja od kojih navodimo relativno mali uzorak ispitanika koji je mogao utjecati na konačne rezultate kao i činjenicu da za uspostavljanje dijagnoze nije korišten strukturirani intervju nego je 
dijagnoza uspostavljana na temelju dijagnostičkih kriterija Međunarodne klasifikacije bolesti, 10. revizija (MKB 10) od strane psihijatra koji je tretirao bolesnika (47). Nedostatak istraživanja predstavlja i nepostojanje potpunih anamnestičkih podataka o ranijem suicidalnom ponašanju, podataka o značajnim životnim događajima koji su prethodili pokušaju suicida kao i potpunih podataka o psihijatrijskom hereditetu i suicidima u obitelji.

\section{ZAKLJUČCI}

1. U analiziranom periodu od 2004.-2013. ukupno je 189 bolesnika hospitalizirano na Klinici za psihijatriju SKB Mostar zbog pokušaja suicida, od čega je bilo 59,2 \% žena i 40,8 \% muškaraca.

2. Žene koje su pokušavale suicid imale su statistički značajno mlađu životnu dob i učestalije su bile neuposlene u odnosu na muškarce dok su muškarci učestalije bili umirovljeni u odnosu na žene.

3. Nije nađeno razlika u učestalosti pokušaja suicida između muškaraca i žena s obzirom na kalendarske karakteristike.

4. Žene koje su pokušavale suicid statistički su značajno učestalije imale dijagnoze iz skupine afektivnih poremećaja i poremećaja ličnosti, dok su muškarci značajno učestalije imali neki od poremećaja iz shizofrenog kruga.

5. Žene su statistički značajno učestalije pokušavale suicid trovanjem, a muškarci tjelesnim ozljeđivanjem.

6. Žene koje su pokušavale suicid statistički su značajno učestalije ranije psihijatrijski liječene od muškaraca dok su muškarci značajno učestalije zloupotrebljavali alkoholna pića i psihoaktivne tvari od žena.

\section{REFERENCE}

1. Hayashi N, Igarashi M, Imai A, Osawa Y, Utsumi K, Ishikawa Y, i sur. Psychiatric disorders and clinical correlates of suicidal patients admitted to a psychiatric hospital in Tokyo. BMC Psychiatry. 2010;10:109.
2. Bertolote JM, Fleischmann A. Suicide and psychiatric diagnosis: a worldwide perspective. World Psychiatry. 2002;1:181-5.

3. Bertolote JM, Fleischmann A. A global perspective in the epidemiology of suicide. Suicidology. 2002;7:6-8.

4. Mathers CD, Loncar D. Projections of global mortality and burden of disease from 2002 to 2030. PLoS Med. 2006;3:442.

5. Krug E. World Report on Violence and Health. Genève: World Health Organization.

6. Alberdi-Sudupe J, Pita-Fernández S, Gómez-Pardiñas SM, Iglesias-Gil-de-Bernabé F, García-Fernández J, Martínez-Sande G, i sur. Suicide attempts and related factors in patients admitted to a general hospital: a ten-year cross-sectional study (1997-2007). BMC Psychiatry. 2011;11:51.

7. Värnik P. Suicide in the world. Int J Environ Res Public Health. 2012;9:760-71.

8. Chang B, Gitlin D, Patel R. The depressed patient and suicidal patient in the emergency department: evidence-based management and treatment strategies. Emerg Med Pract. 2011;13:123.

9. Forman E, Berk M, Henriques G, Brown G, Beck A. History of multiple suicide attempts as a behavioral marker of severe psychopathology. Am J Psychiatry. 2004; 161:437-43.

10. Polewka A, Kroch S, Chrostek Maj J. Suicidal behaviour and suicide attempts in adolescents and young adults-epidemiology, risk factors, prevention and treatment. Przegl Lek. 2004; 61:261-4.

11. Nock MK, Borges G, Bromet EJ, Cha CB, Kessler RC, Lee S. Suicide and suicidal behavior. Epidemiol Rev. 2008;30:133-54.

12. Deveci A, Taskin EO, Erbay Dundar P, Demet MM, Kaya E, Ozmen E, i sur. Prevalence of suicide ideation and attempt in Manisa city centre. Turkish Journal of Psychiatry. 2005;16:1-8.

13. Kocijan-Hercigonja D, Folnegović-Šmalc V. Prepoznavanje, rano otkrivanje i sprečavanje suicidalnosti. Zagreb: Ministarstvo hrvatskih branitelja iz Domovinskog rata; 1999.

14. Owens D, Wood C, Greenwood DC, Hughes T, Dennis M. Mortality and suicide after non-fatal 
self-poisoning: 16-year outcome study. Br J Psychiatry. 2005;187:470-5.

15. Suominen K, Isometsä E, Haukka J, Achte K, Lönnqvist J. Completed suicide after a suicide attempt: a 37-year follow-up study. Am J Psychiatry. 2004;161:563-4.

16. Sverrisson KO, Palsson SP, Sigvaldason K, Kárason S. Clinical aspects and follow up of suicide attempts treated in a general intensive care unit at Landspitali University Hospital in Iceland 2000-2004. Laeknabladid. 2010;96:101-7.

17. Oda S, Higashi T. Current status of research on suicide and suicide prevention in foreign countries. J Nahl Inst Public Health. 2003;52.

18. Nikolaidis G, Zavras D, Bonikos D, Kyriopoulos $\mathrm{J}$. Trends of mortality rates during the last thirty years in Greece. J Med Syst. 2004;28:607-16.

19. Ignjatović-Ristić D, Radević S, Đoković D, Petrović D, Kocić S, Ristić B, i sur. Epidemiological characteristics of suicidal patients admitted to the psychiatric clinic in Kragujevac: A ten-year retrospective study. Srp Arh Celok Lek. 2011;139:26-32.

20. Rančić N, Ignjatović-Ristić D, Radovanović S, Kocić S, Radević S. Sociodemographic and clinical characteristics of hospitalized patients after suicide attempt: a twenty-year retrospective study. Med Glas Ljek komore Zenicko-Doboj kantona. 2012;9:350-5.

21. Mann JJ, Apter A, Bertolote J, Beautrais A, Currier D, Haas A, i sur. Suicide prevention strategies: a systematic review. JAMA. 2005;294:206474.

22. Conwell Y, Duberstein PR, Caine ED. Risk factors for suicide in later life. Biol Psychiatry. 2002;52:193-204.

23. de Graaf R, Sandfort TG, ten Have M. Suicidality and sexual orientation: differences between men and women in a general population-based sample from the Netherlands. Arch Seks Behav. 2006;35:253-62.

24. Gould MS. Suicide and the media. Ann N Y Acad Sci. 2001;932:200-21.

25. Gould MS. Teenage suicide clusters. JAMA. 1990;263:2051-2.
26. Dixon PG, McDonald AN, Scheitlin KN, Stapleton JE, Allen JS, Carter WM, i sur. Effects of temperature variation on suicide in five U.S. counties, 1991-2001. Int J Biometeorol. 2007;51:395-403.

27. Tsirigotis K, Gruszczynski W, Tsirigotis M. Gender differentiation in methods of suicide attempts. Med Sci Monit. 2011;17:65-70.

28. Hall RC, Platt DE, Hall RC. Suicide risk assessment: a review of risk factors for suicide in 100 patients who made severe suicide attempts. Evaluation of suicide risk in a time of managed care. Psychosomatics. 1999;40:18-27.

29. Canetto SS, Sakinofsky I. The gender paradox in suicide. Suicide Life Threat Behav. 1998;28:1-23.

30 . Welch SS. A review of the literature on the epidemiology of parasuicide in the general population. Psychiatr Serv. 2001;52:368-75.

31. Ristić-Ignjatović $\mathrm{D}$, Ilić $\mathrm{M}$, Selaković Z. Pokušaji suicida: retrospektivna analiza hospitalizovanih pacijenata u Psihijatrijskoj klinici KBC "Kragujevac". Medicinski časopis. 2005;1:28-32.

32. Vijayakumar L, John S, Pirkis J, Whiteford H. Suicide in developing countries (2): risk factors. Crisis. 2005;26:112-9.

33. Nakaji S, Parodi S, Fontana V, Umeda T, Suzuki $\mathrm{K}$, Sakamoto J i sur. Seasonal changes in mortality rates from main causes of death in Japan (1970--1999). Eur J Epidemiol. 2004;19:905-13.

34. Petridou E, Papadopoulos FC, Frangakis CE, Skalkidou A, Trichopoulos DA. Role of sunshine in the triggering of suicide. Epidemiology. 2002;13:106-9.

35. Nock MK, Borges G, Bromet EJ, Alonso J, Angermeyer $\mathrm{M}$, Beautrais $\mathrm{A}$ i sur. Cross-national prevalence and risk factors for suicidal ideation, plans and attempts. Br J Psychiatry. 2008;192:98105.

36. Kessler RC, Borges G, Walters EE. Prevalence of and risk factors for lifetime suicide attempts in the National Comorbidity Survey. Arch Gen Psychiatry. 1999;56:617-26.

37. Mann JJ, Waternaux C, Haas GL, Malone KM. Toward a clinical model of suicidal behavior in psychiatric patients. Am J Psychiatry. 1999;156:1819. 
38. Shaffer D, Gould MS, Fisher P, Trautman P, Moreau D, Kleinman M, i sur. Psychiatric diagnosis in child and adolescent suicide. Arch Gen Psychiatry. 1996;53:339-48.

39. Yen S, Shea MT, Pagano M, Sanislow CA, Grilo CM, McGlashan TH, i sur. Axis I and axis II disorders as predictors of prospective suicide attempts: findings from the collaborative longitudinal personality disorders study. J Abnorm Psychol. 2003;112:375-81.

40. Yamada T, Kawanishi C, Hasegawa H, Sato R, Konishi A, Kato D, i sur. Psychiatric assessment of suicide attempters in Japan: a pilot study at a critical emergency unit in an urban area. BMC Psychiatry. 2007;7:64.
41. Nock MK, Kessler RC. Prevalence of and risk factors for suicide attempts versus suicide gestures: analysis of the National Comorbidity Survey. J Abnorm Psychol. 2006;115:616-23.

42. Beautrais AL. Gender issues in youth suicidal behaviour Emerg Med (Frementle) 2002;14:35-42.

43. Baca-García E, Diaz-Sastre C, Resa EG, Blasco H, Conesa DB, Saiz-Ruiz J, i sur. Variables associated with hospitalization decisions by emergency psychiatrists after a patient's suicide attempt. Psychiatr Serv. 2004;55:792-7.

44. Asukai N. Sucide and mental disorders. Psychiatry Clin Neurosci.1995;49:91-97.

45. Heikkinen M, Aro H, Lönnqvist J. Recent life events, social support and suicide. Acta Psychiatr Scand Suppl. 1994;377:65-72.

46. Suominen K, Henriksson M, Suokas J, Isometsä E, Ostamo A, Lönnqvist J. Mental disorders and comorbidity in attempted suicide. Acta Psychiatr Scand. 1996;94:234-40.

47. Folnegović Šmalc V. Klasifikacija mentalnih poremećaja i poremećaja ponašanja: MKB-10-deseta revizija. Zagreb: Medicinska naklada; 1999. 


\title{
THE PREVALENCE OF SUICIDALITY IN PATIENTS HOSPITALIZED AT THE PSYCHIATRIC CLINIC OF THE UNIVERSITY CLINICAL HOSPITAL MOSTAR IN THE PERIOD FROM 2004 TO 2013
}

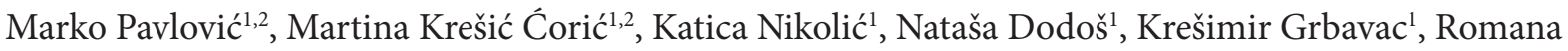 \\ Babić1 ${ }^{1}$ Sanjin Lovrić ${ }^{1}$, Bojan Bender ${ }^{1}$, Sanja Burić ${ }^{1}$, Dragan Babić ${ }^{1,2}$ \\ ${ }^{1}$ Psychiatric Clinic, University Clinical Hospital Mostar, 88000 Mostar, Bosnia and Herzegovina \\ ${ }^{2}$ The Faculty of Medicine, University of Mostar, 88000 Mostar, Bosnia and Herzegovina
}

\begin{abstract}
INTRODUCTION: Despite the evident progress of medicine and psychiatry, the increase in suicidality of psychiatric patients has been registered in recent decades. People who are, due to some form of suicidal behavior, hospitalized in psychiatric institutions represent a population with a particularly high risk of subsequent suicide.

OBJECTIVE: To investigate the incidence of suicide and epidemiological characteristics of suicidal patients hospitalized at the Psychiatric Clinic of the University Clinical Hospital (UCH) Mostar.

METHODS: A retrospective study analyzed data from 189 case histories of patients who were hospitalized at the Clinic for Psychiatry UCH Mostar in the period from 2004 to 2013.

RESULTS: Patients who attempted suicide were more likely to be female (59.2\%), the unemployed (47.6 \%), intermediate level education (52.4 \%), married (45.5\%), without children (37,6\%) and are more often coming from urban areas (75.7\%). There was no difference in the incidence of suicide attempts among men and women regarding the calendar features. Considering statistics, a diagnosis from a group of affective and personality disorders was more frequent in women, while, on the other hand, statistics showed that men more frequently suffered from psychotic disorders $(\mathrm{p}=0.003)$. The most common method of suicide attempts was poisoning (54.0\%), and considering sex significantly higher rate was in women $(\mathrm{p}<0.001)$. Men more frequently attempted suicide by physical injuries $(\mathrm{p}<0.001)$, and alcoholic abuse $(\mathrm{p}=0.001)$ and by taking psychoactive substances $(\mathrm{p}=0.003)$ compared to women.

CONCLUSION: Suicide attempts were more frequent in females. Women more frequently had a diagnosis from a group of affective and personality disorders, while men more frequently suffered from psychotic disorders. Women more frequently tried to commit suicide by poisoning, and men by physical injuries.
\end{abstract}

Keywords: suicide attempts, hospitalization, retrospective study

Correspondence:

M.Sc. Marko Pavlović, MD.

e-mail: makijato29@gmail.com 